\title{
Breccia-Pipe Uranium Mining in Northern Arizona- Estimate of Resources and Assessment of Historical Effects
}

\begin{abstract}
bout 1 million acres of Federal Aland in the Grand Canyon region of Arizona were temporarily withdrawn from new mining claims in July 2009 by the Secretary of the Interior because of concern that increased uranium mining could have negative impacts on the land, water, people, and wildlife. During a 2-year interval, a Federal team led by the Bureau of Land Management is evaluating the effects of withdrawing these lands for extended periods. As part of this team, the U.S. Geological Survey (USGS) conducted a series of short-term studies to examine the historical effects of breccia-pipe uranium mining in the region. The USGS studies provide estimates of uranium resources affected by the possible land withdrawal, examine the effects of previous breccia-pipe mining, summarize water-chemistry data for streams and springs, and investigate potential biological pathways of exposure to uranium and associated contaminants. This fact sheet summarizes results through December 2009 and outlines further research needs.
\end{abstract}

\section{Introduction}

Citing concerns that uranium mining could have adverse effects on the Grand Canyon watershed, its people, and wildlife, on July 21, 2009, Secretary of the Interior Ken Salazar withdrew about 1 million acres of Federal land near Grand Canyon from new mining claims for 2 years. Mining of uranium can release toxic and hazardous substances to the environment. These include uranium itself, which is a toxic chemical and can pose a radiation hazard, and arsenic and other toxic trace metals. At the Secretary's request, the U.S. Geological Survey (USGS) conducted a series of short-term studies to examine the effect of brecciapipe uranium mining in the region. USGS

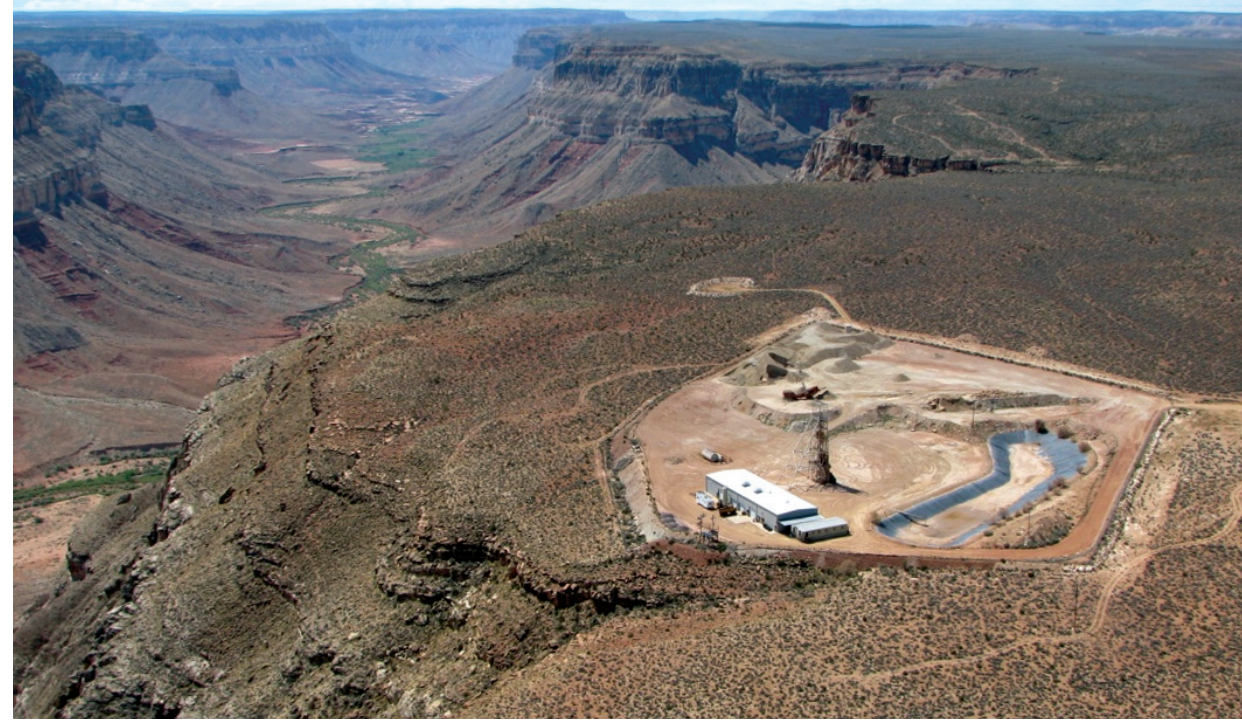

Figure 1. The Kanab North Mine is one of several breccia-pipe uranium mines in northern Arizona. USGS scientists conducted field assessments at this mine, where operations are currently on standby (USGS photo by Don Bills).

findings will be used in an environmental assessment process to examine the potential effects of future mining activities. This fact sheet summarizes USGS research completed through December 2009 and presented in USGS Scientific Investigations Report 2010-5025 (Alpine, 2010; http://pubs.usgs.gov/sir/2010/5025/).

\section{Background}

Some of the highest grade uranium ore in the United States occurs in breccia pipes scattered across the Grand Canyon region (fig.1). These breccia pipes, named for their vertical, pipe-like shape and the broken rock, or breccia, that fills them, range from 300 to $500 \mathrm{ft}$ in diameter at depth. They were formed millions of years ago when groundwater dissolved carbonate rock and created vertical cavities into which surrounding rock collapsed. Later, highly mineralized groundwater from overlying or underlying rocks, moving vertically through the porous breccia, deposited ore minerals - including uranium - in some of the pipes. When exposed to the atmosphere, either naturally through erosion or by mining, these minerals may be dissolved or broken down and dispersed by wind and water.

Uranium mining in the Grand Canyon region peaked in the 1980s. However, there is now renewed interest in the exploration and mining of breccia pipes in the region-uranium prices have increased, and concerns about clean energy and energy independence also have focused attention on uranium and nuclear energy. Currently, there are 104 U.S. nuclear reactors, which annually consume about 27,500 tons of uranium oxide, the primary constituent of the fuel rods that power them. Each year, about 1,750 to 2,250 tons of uranium oxide are mined domestically. The remainder of the uranium oxide needed to fuel U.S. reactors comes from foreign sources, primarily Canada, and the U.S. utility inventory.

Increased mining in northern Arizona could help meet the U.S. demand for uranium but could also increase the amount of uranium and other trace elements in the local surface water and groundwater 
flowing into Grand Canyon National Park and the Colorado River. Deep mining activities could allow uranium and other trace elements to be mobilized by water and transported into perched water-bearing zones and the regional aquifer, which are sources of water for local communities and feed springs used by recreationists, fish, and other wildlife. Additionally, waste rock, ore, and dust from mined areas, if not properly managed, could be transported away from the mines by wind and flood events.

The Secretary of the Interior cited such concerns when he withdrew Federal land near Grand Canyon from new mining claims for 2 years. The land proposed for withdrawal comprises three parcels (fig.2) - two parcels managed primarily by the Bureau of Land Management (BLM) to the north of Grand Canyon (North and East Segregation Areas) and one parcel managed by the Forest Service on the Kaibab National Forest south of Grand Canyon (South Segregation Area).

At the Secretary's request, the USGS began a series of short-term studies to provide (1) estimates of the uranium resource located on Federal lands proposed for withdrawal and those previously withdrawn from mineral mining, (2) an examination of surface contamination resulting from historical (1980s) mining, (3) analyses of surface water and groundwater to determine if previous mining has affected water quality, (4) compilation of the available information on exposure pathways and biological effects of uranium and associated contaminants for plants and animals, and (5) a geological map of the House Rock Valley area (East Segregation Area), Coconino County, Arizona, with detailed stratigraphic and structural information (published

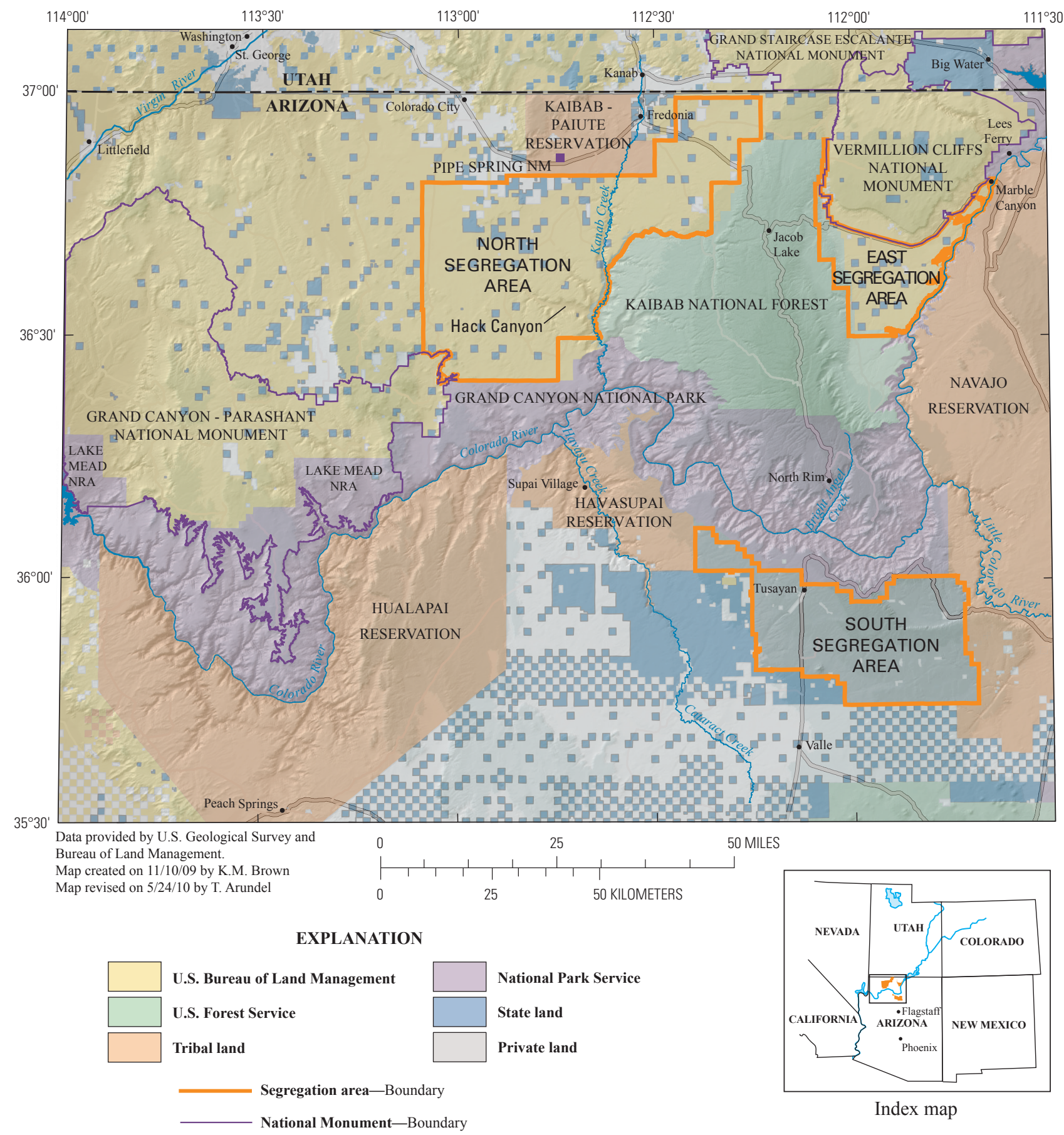

Figure 2. Map of northwestern Arizona showing land ownership and the lands proposed for withdrawal from mining (the three Segregation Areas). 
separately). Results of those studies are presented in Alpine (2010), and items 1 to 4 are summarized in this fact sheet.

\section{Uranium Resource Availability}

In 1990, the USGS estimated that northern Arizona breccia pipes contained a mean undiscovered uranium endowment of 1.3 million tons of uranium oxide (Finch and others, 1990). This estimate, which is an average of high (2.8 million tons) and low (339,000 tons) probability estimates, is about three times the total current uranium reserves in the rest of the United States (445,000 tons uranium oxide), as estimated in December 2003 by the U.S. Energy Information Administration. In northern Arizona, the combined uranium production for mines in the North and South Segregation Areas through 1994 was 11,650 tons.

In 2009, the USGS examined how much of the northern Arizona uranium endowment was made unavailable for exploration, development, or mining by previous withdrawals of Federal land and by the proposed withdrawal (Alpine, 2010, chapter A). Areas excluded from mining before July 2009_including the national park, two national monuments, a game preserve on forest lands, and Tribal lands - contain an estimated 466,384 tons of uranium oxide, or about 35 percent of the total uranium endowment estimated for northern Arizona. The 2009 estimate for the North, South, and East Segregation Areas is 162,964 tons of uranium oxide, or about 12 percent of the total uranium endowment estimated for northern Arizona. Combined, these three parcels and previously withdrawn areas contain about 48 percent of the total estimated uranium endowment in northern Arizona (fig. 3). However, the 1990 USGS report estimated that most of northern Arizona's uranium resources occur in a "most favorable area"- the area defined by Finch and others (1990) as potentially most productive for uranium resource development - that includes all the lands already withdrawn or proposed for withdrawal. Those lands combined would represent 69 percent of the 910,000 tons of uranium oxide estimated to occur in that favorable area.

\section{Effects of 1980s Uranium Mining}

In August and October 2009, USGS scientists conducted field assessments in

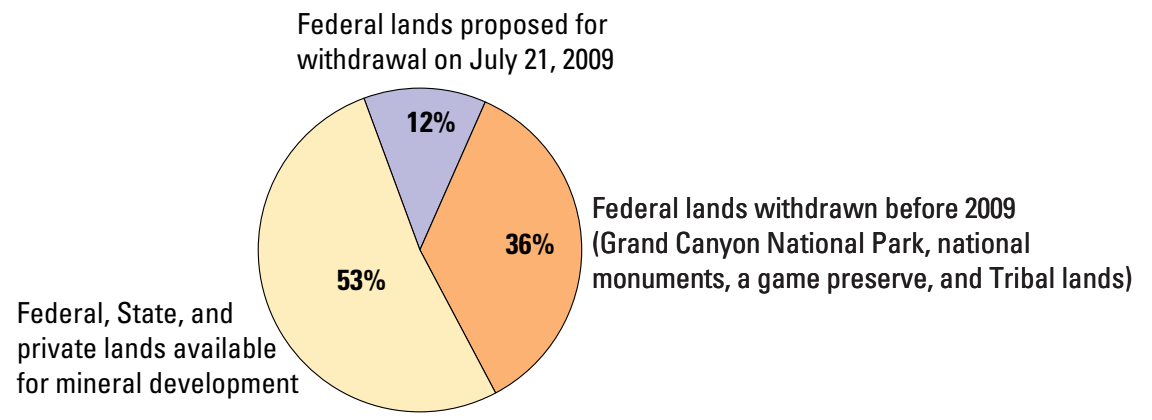

Figure 3. Pie diagram showing percentages of the total estimated mean uranium deposit in northern Arizona for lands proposed for withdrawal from new mining on July 21, 2009, for lands withdrawn from mining before July 21,2009 , and for lands available for new mineral development.

and around several reclaimed or inactive breccia-pipe uranium mines on BLM lands in the Kanab Creek area north of Grand Canyon National Park. Surface soil, sediment, and mined waste-rock samples were collected at six different sites that represent various stages of mining - mined and reclaimed, partially mined and on standby, and mineralized and explored by drilling but not minedand at an undisturbed area.

Samples taken at breccia-pipe mine sites were analyzed to determine historical dispersion of uranium and other trace elements by wind and water. Some samples were leached to simulate the potential mobility of uranium and other trace elements during weathering. Findings were compared to existing data for the region. For example, previous research indicated that naturally occurring levels of as much as 5.6 parts per million (ppm) uranium and 39 ppm arsenic can be present in undisturbed soil and sediment; the average soil uranium concentration in a regional survey was $2.4 \mathrm{ppm}$. Radioactivity surveys were also conducted in 2009 to determine the levels of exposure to radioactivity at each site.

Results of these studies included the following (Alpine, 2010, chapter B): (1) Uranium and arsenic were consistently the most abundant trace elements of concern at mined sites - the combined mean concentrations for the five mining sites evaluated were 9 ppm uranium and 18 ppm arsenic. The undisturbed area had uranium and arsenic values at or below the natural background. (2) Waste rock and ore at one mine in Hack Canyon have been washed downstream by flash floods during mining operations and again after reclamation.

(3) Wind dispersion of uranium-rich dust was evident at three sites. Soil contamination was greatest adjacent to a mine on standby status, where ore and waste rock have been at the surface for about 20 years. (4) Experimental data indicated that uranium solubility increases with increased weathering and that leached trace-element concentrations derived from waste rock or ore can be very high. However, the dilution factors during flood events are also very high. (5) Finally, there was evidence of elevated but highly variable radioactivity at all mine sites.

\section{Water Chemistry of Wells, Perennial and Intermittent Streams, and Springs}

To understand how water quality may be affected by uranium mining activities, USGS scientists evaluated both historical water-chemistry data and analyses of groundwater samples collected in 2009 (Alpine, 2010, chapter C). Historical data for 1,014 samples from 428 sites in the Grand Canyon region, including wells, streams, and springs, indicated that 95 percent of samples had concentrations of dissolved uranium less than 30 micrograms per liter $(\mu \mathrm{g} / \mathrm{L})$, the U.S. Environmental Protection Agency (EPA) maximum contaminant level for drinking water. Sixty-six percent of samples contained dissolved uranium concentrations of $5 \mu \mathrm{g} / \mathrm{L}$ or less and were classified as low concentrations for the Grand Canyon region on the basis of historical data. Samples of surface water from the Colorado River in the Grand Canyon region typically contained less than $5 \mu \mathrm{g} / \mathrm{L}$ dissolved uranium. However, about 70 of the 428 sites exceeded the EPA's primary and secondary maximum contaminant levels for drinking water for a few major 


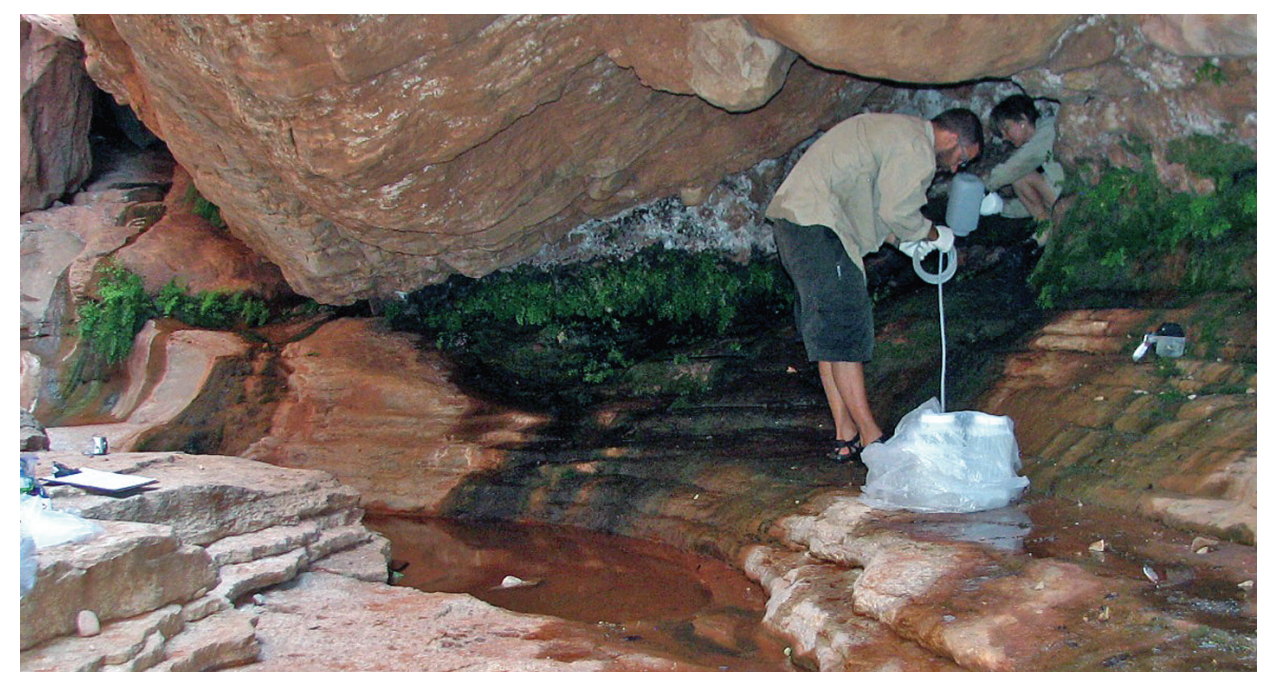

Figure 4. USGS scientists taking a water sample at Buck Farm Spring, which was 1 of 20 springs sampled as part of new research to investigate possible impacts of uranium mining in northern Arizona. Sites selected for sampling were designed to fill gaps in historical water-chemistry data in the region. (USGS photo by Nancy Hornewer.)

ions and trace elements, such as arsenic, iron, lead, and sulfate.

Historical samples from about 120 springs and 32 streams in the region showed dissolved uranium concentrations greater than $5 \mu \mathrm{g} / \mathrm{L}$ but less than $30 \mu \mathrm{g} / \mathrm{L}$; those concentrations are thought to be the result of natural dissolution and erosion of mineralized ore deposits. Samples from 15 springs and 5 wells in the region contained dissolved uranium concentrations greater than the $30-\mu \mathrm{g} / \mathrm{L}$ limit. These sites are close by or in direct contact with mineralized ore bodies, and the elevated concentrations may be related to natural processes, mining, or both.

In August and September 2009, groundwater samples were collected from 24 sites (springs and wells; fig. 4) in the study area to supplement the historical dataset and evaluate the impacts of legacy mining. Analysis of this limited dataset showed that concentrations of dissolved uranium and arsenic were not significantly different between mined and unmined areas. Dissolved uranium concentrations in samples collected from wells and springs that discharge from perched waterbearing zones were higher than $5 \mu \mathrm{g} / \mathrm{L}$ but still below the EPA limit.

\section{Biological Pathways of Exposure for Uranium and Associated Radioactive Contaminants}

Various species of plants and animals found on the lands proposed for withdrawal are considered species of concern by State and Federal agencies. Previous studies have reported that uranium and associated radioactive contaminants, or radionuclides, can affect the survival, growth, and reproduction of plants and animals. Exposure to chemical and radiation hazards is influenced by life history and surrounding environment. For example, the use of burrows in uranium-rich areas by some species of reptiles, amphibians, birds, and mammals is of particular concern.

USGS scientists examined known chemical and radiation hazards associated with uranium and developed possible exposure pathways and a food web that is specific to the lands considered for withdrawal (Alpine, 2010, chapter D). Overall, USGS scientists found only limited chemical toxicity data available for plants and tissue concentrations of uranium and other radionuclides were available for only two species of concern in the Grand Canyon region. This lack of information makes it difficult to conduct a meaningful ecological risk assessment without further research. In the absence of such data, understanding the pathways by which plants and animals may be exposed to uranium and associated contaminants is critical to minimizing risk.

\section{Future Research}

The results of these short-term studies by the USGS underscore data and information gaps that make it difficult for resource managers and decisionmakers to fully animals of concern. In addition, measured evaluate uranium mining impacts in northern Arizona. For example, detailed data on uranium isotope geochemistry could be used to help differentiate between natural and mining-derived sources of uranium. Similarly, chemical data for the sediment of the Colorado River and its tributaries could provide information about the source and mobility of uranium and other associated metals. Additional wells distributed throughout the region would help improve the understanding of groundwater movement and potential risks to the region's water from uranium mining. Information on the sensitivity of the region's plants and animals to uranium and on present uranium concentration in their tissues is essential for evaluating the risks to species of concern.

The USGS continues to assist the BLM with the environmental impact statement process to assess the proposed withdrawal. USGS scientists will be evaluating additional sources of data, collecting and evaluating additional water samples to determine if high concentrations of dissolved uranium detected in the historical record persist, and establishing monitoring sites to evaluate past, current, and future mining impacts.

Donald J. Bills, Kristin M. Brown, Andrea E. Alpine, James K. Otton, Bradley S. Van Gosen, Jo Ellen Hinck, and Fred D Tillman

\section{References Cited}

Alpine, Andrea E., ed., 2010, Hydrological, geological, and biological site characterization of breccia pipe uranium deposits in northern Arizona: U.S. Geological Survey Scientific Investigations Report 2010-5025, 353 p., 1 pl., scale 1:375,000

Finch, W.I., Sutphin, H.B., Pierson, C.T., McCammon, R.B., and Wenrich, K.J., 1990, The 1987 estimate of undiscovered uranium endowment in solution-collapse breccia pipes in the Grand Canyon region of northern Arizona and adjacent Utah: U.S. Geological Survey Circular 1051, 19 p.

$$
\begin{gathered}
\text { For more information contact: } \\
\text { John Hoffmann } \\
\text { U.S. Geological Survey } \\
\text { Arizona Water Science Center } \\
520 \text { N. Park Ave., Suite } 221 \\
\text { Tucson, AZ, } 85719 \\
\text { 520-670-6671 (ext. 222) }
\end{gathered}
$$

This Fact Sheet and any updates to it are available online at http://pubs.usgs.gov/fs/2010/3050/ 